\title{
STUDIES ON RANCIDITY INHIBITION IN FROZEN \\ HORSE MACKEREL (Trachurus trachurus) BY CITRIC \\ AND ASCORBIC ACIDS
}

Santiago P. Aubourg, Francisco Pérez-Alonso and José M. Gallardo

Instituto de Investigaciones Marinas (CSIC)

Eduardo cabello, 6

36208-VIGO (Spain)

Phone: +34 986231930

Fax: +34 986231930

e-mail: saubourg@iim.csic.es

Running Title: Rancidity inhibition in frozen horse mackerel

Key Words: Frozen storage, horse mackerel, fillets and whole fish, lipid oxidation, citric acid, ascorbic acid, shelf life 


\section{SUMMARY}

The study is aimed to investigate the effect of aqueous solutions of citric (CA) and ascorbic (AA) acids on the lipid stability of horse mackerel (Trachurus trachurus) fillets and whole fish during frozen storage (up to 6 and 9 months, respectively) by means of a soaking pretreatment. Best oxidation inhibition results on fish fillets were obtained when employing a $0.50 \%$ CA solution; lower $(\mathrm{p}<0.05)$ peroxide (month 3 ), thiobarbituric acid reactive substances (months 1 and 3) and fluorescent compounds formation (month 6) values were obtained than those of the untreated (Blank Control) and water treated (Water Control) fish fillets. In the case of whole fish, soaking pretreatment with a mixture consisting of $0.50 \% \mathrm{CA}$ and $0.50 \%$ AA showed the best results at inhibiting oxidation, as lower $(\mathrm{p}<0.05)$ peroxide formation was observed at 6 and 9 months of frozen storage compared to the untreated or water soaked counterparts. Advantages of both acids (CA and AA) are discussed and further studies based on the positive role of a CA-AA mixture will be carried out to extend the shelf life time of medium- and high-fat content fish species during frozen storage.

\section{INTRODUCTION}

Most fish and other marine species give rise to products of great economic importance in many countries. Freezing and frozen storage have been largely employed to retain fish sensory and nutritional properties before it is consumed or used in other technological processes [1,2]. However, during frozen storage, enzymatic and nonenzymatic rancidity is known to strongly influence the shelf life of marine products 
[3,4]. This is due to the highly unsaturated lipid composition [5] and the presence of prooxidant molecules in the muscle of marine species [6,7].

To extend the lag phase of lipid oxidation as a long as possible and thereby, increase the shelf life, a great deal of attention is being directed toward to the employment of antioxidants [8,9]. Recent efforts are focused on the replacement of synthetic antioxidants by natural ones, which may provide nutritional and therapeutic effects [10]. Naturally occurring antioxidants have been successfully employed with marine oils [11], minced fish [12] and canned fish [13]. Soaking pretreatment of fish fillets has also led to lipid oxidation inhibition [14-17].

Citric acid (CA) and its salts are widely known for their role as chelators and acidulants in biological systems. CA has been proven to inhibit microbial growth [18], to improve physical and sensory properties in frozen fish products [19] and to favour gelatine production [20]. As it relates to the inhibition of lipid oxidation, CA has been shown to play a synergist role with primary antioxidants and oxygen scavengers during vegetable oil storage [21] and minced fish processing [22]. In the same way, ascorbic acid (AA) and its salts have been reported to act as synergists of primary antioxidants in fish oil [12], minced fish [23] and fish fillets [24] because of their oxygen scavenger and reducing roles.

The present work concerns horse mackerel (Trachurus trachurus) trading as a frozen product. Horse mackerel is a medium-fat containing fish abundant in the Northeast Atlantic [25] that has recently captivated a great deal of commercial interest $[26,27]$. The study was aimed to investigate the effect of citric and ascorbic acids on the lipid stability of horse mackerel fillets and whole fish during frozen storage by means of a soaking pretreatment. Employment of different CA levels were investigated as was the presence and absence of AA in the soak solution. 


\section{MATERIALS AND METHODS}

\section{Raw fish, sampling and processing}

Filleted fish experiment: Fresh horse mackerel (Trachurus trachurus) were captured in April 2001 and kept on ice (6 hours) till delivery to the laboratory. Then, the fish were carefully gutted, dressed and filleted by hand, divided into five groups and kept on ice. Each group included 18 fishes. Individuals of the first group were left untreated (Blank Control), directly packaged in polyethylene bags and immediately frozen at $-80^{\circ} \mathrm{C}$. The remaining four groups were immersed in the following four aqueous solutions: Distilled water (Water Control), $0.05 \%$ CA, $0.15 \%$ CA and $0.50 \%$ CA. The fillets were removed after $5 \mathrm{~min}$, packaged in polyethylene bags and frozen at $-80^{\circ} \mathrm{C}$. After $24 \mathrm{hr}$ at $-80^{\circ} \mathrm{C}$, all fish fillets were moved to a $-20^{\circ} \mathrm{C}$ freezer. Sampling was undertaken after 1,3 and 6 months of frozen storage at $-20^{\circ} \mathrm{C}$ and on the starting material (Raw values). For each treatment, three different fish batches were considered and studied separately to achieve the statistical study. One analytical determination was carried out on each sampling from each batch, that included fillets from two fishes.

Whole fish experiment: Fresh horse mackerel were captured in February 2002 and kept on ice (6 hours) till delivery to the laboratory. Then, the fish were divided into six groups and kept on ice. Each group included 24 fishes. Individuals of the first group were left untreated (Blank Control), directly packaged in polyethylene bags and immediately frozen at $-80^{\circ} \mathrm{C}$. The five remaining groups were immersed in the following five aqueous solutions: Distilled water (Water Control), $0.50 \%$ AA, $0.50 \%$ CA, $0.50 \%$ AA $+0.50 \%$ CA (0.50 \% AA-CA $)$ and $0.25 \%$ AA + $0.25 \%$ CA $(0.25 \%$ AA-CA). The fish were removed after 15 min of soaking, packaged in polyethylene bags and frozen at $-80^{\circ} \mathrm{C}$. After $24 \mathrm{hr}$ at $-80^{\circ} \mathrm{C}$, all fish samples were moved to a $-20^{\circ} \mathrm{C}$ 
freezer. Sampling was undertaken after 1, 3, 6 and 9 months of frozen storage at $-20^{\circ} \mathrm{C}$ and on the starting material (Raw values). For each treatment, three different fish batches were considered and studied separately to achieve the statistical study. One analytical determination was carried out on each sampling from each batch, that included fillets from two fishes.

\section{Chemicals and general analyses}

Chemicals employed in the present work (i.e., solvents, general and specific reagents) were reagent grade (E. Merck; Darmstadt, Germany) unless otherwise specified.

The moisture content was determined by weight difference between the homogenized fish muscle (1-2 g) and after $24 \mathrm{hr}$ at $105^{\circ} \mathrm{C}$. Results are expressed as $\mathrm{g}$ water/100 g muscle. Lipids were extracted by the Bligh and Dyer [28] method. Quantification results are expressed as g total lipids/100 g wet muscle. A 10 g portion of fish muscle was homogenized in $50 \mathrm{ml}$ of distilled water and its $\mathrm{pH}$ was measured at room temperature.

\section{Lipid damage measurements}

As frozen fish quality has shown a great dependence on lipid hydrolysis and oxidation, the following lipid damage measurements were chosen as representative of lipid hydrolysis (free fatty acids), primary (peroxide value), secondary (thiobarbituric acid index) and tertiary (fluorescent compounds) lipid oxidation.

Free fatty acids (FFA) content was determined in the lipid extract by the Lowry \& Tinsley [29] method based on complex formation with cupric acetate-pyridine. Results are expressed as g FFA/100 g lipids. 
The peroxide value (PV) was expressed as meq active oxygen/kg lipid and was determined in the lipid extract by the ferric thiocyanate method [30].

The thiobarbituric acid index (TBA-i) was determined in trichloracetic acid extract from the fish muscle according to Vyncke [31]. Results are expressed as mg malondialdehyde equivalents/kg fish sample.

Fluorescence formation (Perkin-Elmer LS 3B) at 327/415 nm and 393/463 nm was studied as described elsewhere [32]. The relative fluorescence (RF) was calculated as follows: $\mathrm{RF}=\mathrm{F} / \mathrm{F}_{\mathrm{st}}$, where $\mathrm{F}$ is the fluorescence measured at each excitation/emission pair, and $F_{\text {st }}$ is the fluorescence intensity of a quinine sulphate solution $(1 \mu \mathrm{g} / \mathrm{ml}$ in 0.05 $\mathrm{M} \mathrm{H}_{2} \mathrm{SO}_{4}$ ) at the corresponding wavelength. The fluorescence ratio (FR) was obtained from the lipid extract [28] analysis, according to the following calculation: FR = $\mathrm{RF}_{393 / 463 \mathrm{~nm}} / \mathrm{RF}_{327 / 415 \mathrm{~nm}}$.

\section{Statistical analyses}

Data from the different lipid damage measurements were subjected to a one-way ANOVA $(\mathrm{p}<0.05)$ [33]. Comparison of means was performed using a least-squares difference (LSD) method.

\section{RESULTS AND DISCUSSION}

\section{Filleted fish experiment}

The moisture content in white muscle of fish fillets ranged between $76 \%$ and $80 \%$ while the lipid content varied between $0.70 \%$ and $1.85 \%$, on a wet basis. These ranges are due to variation in individual fish, and are not arising from antioxidant 
treatment or frozen storage time. Comparison of these ranges with those of previous research showed a higher moisture content for horse mackerel than for fattier fish species [34] and a lower moisture content than for leaner fish species [35], in accordance with an inverse ratio between moisture and lipid matter [36].

$\mathrm{pH}$ values ranged between 6.3 and 6.9 in all samples; no statistical differences were obtained arising from the presence of antioxidant or the storage time.

Lipid damage indices measured in the filleted fish experiment are presented in Tables 1-4. As a result of frozen storage, a gradual increase in FFA formation was observed for all samples (Table 1), thereby indicating that hydrolytic activity of lipid constituents was occurring over time. Comparison among the different treatments did not show significant differences at months 1 and 3. At month 6 however, the $0.05 \%$ CA treated samples showed a significantly lower FFA level than the other treatments, except for the Blank Control.

Examining the extent of lipid hydrolysis was deemed important to the study because FFA formation has previously proved a great incidence on lipid oxidation [37,38] and a high degree of lipid hydrolysis has already been observed in horse mackerel during frozen storage [26,39].

Peroxide values remained low at month 1 for all samples (Table 2), but increased at month 3 for both Controls; at the same time, mean values obtained for CAtreated samples showed an increasing trend. Compared to month 3, a marked increase was observed for all samples at month 6. Comparison among the different treatments showed a significantly higher peroxides formation at months 3 and 6 for the Blank Control than for remaining samples. Compared to the Water Control, the $0.05 \%$ and 0.50\% CA treatments retarded peroxide development at month 3 . No significant differences were obtained among the three different CA concentrations tested. 
Secondary lipid oxidation products, as reported by the TBA-i showed a gradual increase for all samples during the course of the study (Table 3). Comparison of the different treatments revealed that the $0.50 \%$ CA treatment was effective at months 1 and 3, as lower TBA-i values were obtained compared to both Controls; at month 3, 0.05\% and $0.15 \%$ CA treatments also showed to be effective. At all sampling times, the Blank Control showed higher values than the remaining samples.

Interaction compounds produced between oxidized lipids and nucleophilic compounds present in the fish tissue (free amino acids, peptides, proteins, aminated phospholipids) were followed by fluorescence detection (Table 4). Till month 3, a significant increase was only observed in the Blank Control. Then, at the end of the experiment, a general increase was noted in all cases and according to primary and secondary lipid oxidation formation (Tables 1 and 2). Comparison among the different treatments did not show significant differences at months 1 and 3. At month 6 however, the $0.15 \%$ and $0.50 \%$ CA treated samples showed a lower extent of fluorescence formation compared to both the Blank and Water Controls. No significant differences were obtained among the three CA concentrations tested.

Compared to both Controls, the $0.50 \%$ CA treatment retarded oxidative development at months 1 and 3 according to TBA-i data, at month 3 according to PV and at month 6 according to the FR value. The positive role of CA can be explained by chelation of heavy metal ions, so that the catalytic effect of these ions on peroxide decomposition during frozen storage would be diminished [40,41]. The present results offer a possibility of extending the shelf life period during frozen storage of fillets from horse mackerel (one month without treatment) [17], so that trading of this underutilized fish species could be expanded. 
Water treatment of fillets (Water Control) also showed some inhibition of oxidation, according to peroxide (months 3 and 6) and TBA-i (months 1 and 3) values. This inhibitory effect has been explained in previous studies [42,43] as a result of blood removal from fish. In other words, the content of prooxidant molecules (i.e., hemoproteins and metal ions) in the fillet decreases. However, as water soluble endogenous antioxidants in fish fillet (e.g., ascorbate, glutathione peroxidase) might also be lost during the washing treatment $[42,44]$, soaking the fillets with an antioxidant solution has been recommended [43].

\section{Whole fish experiment}

The mean values obtained for moisture, lipid and $\mathrm{pH}$ determinations were in the same ranges as those in the filleted fish experiment. Concerning these three parameters, no differences were observed related to the antioxidant treatment or the frozen storage time.

Lipid damage indices measured in the whole fish experiment are presented in Tables 5-8. As a result of the frozen storage, a gradual increase in the FFA formation was observed in all fish samples thereby indicating that hydrolytic activity of lipid constituents was occurring over time (Table 5). Comparison among the different treatments showed few significant differences. At month 1, a higher hydrolytic development was observed for both acid mixtures than for either Control sample. By the end of the experiment, a lower lipid hydrolysis development was observed in the $0.50 \%$ AA-CA treated samples compared to that of the Water Control.

As in the case of fillets, a direct relationship between FFA formation and any of the treatments employed could not be observed. No significant differences were found by comparing the hydrolytic activity of Blank Controls corresponding to fillets and 
whole fish. Lipase and phospholipase activities were not influenced by the presentation (whole fish or fillet) of the product nor by the addition of an antioxidant. Previous studies have shown that hydrolysis was partially inhibited by addition of salts such as $\mathrm{NaOCl}$ and $\mathrm{NaF}$ [45] and $\mathrm{NaCl}[39]$.

The PVs increased slowly till month 6 in all samples (Table 6). However, at month 9 a marked increase was observed for all treatments. Comparison among treatment means showed at month 6 a lower level for fish samples treated with any of the AA-CA mixtures than in the case of the Blank and Water Controls. By the end of the experiment, a lower level was observed for the $0.50 \%$ AA-CA treated samples compared to both Controls. Both antioxidants (AA and CA) when employed individually did not provide an inhibitory effect on the peroxides formation during the course of the study, nor did the water treatment.

During frozen storage, a slow increase in TBA-i values was observed for each treatment (Table 7). Comparison among treatments showed only significant differences at month 6, when comparing $0.50 \%$ AA, $0.50 \%$ CA and $0.50 \%$ AA-CA treated samples with the Blank Control. However, comparison with the Water Control did not lead to significant differences for any of the antioxidant treatments.

The formation of fluorescent compounds during frozen storage (Table 8) showed a slight increase for all samples at month 6, followed by a sharp increase by month 9 . Comparison among the different treatments only led to significant differences at month 1 between both AA-CA mixture treatments and the Blank Control.

Comparison of results from the whole fish and fillet experiments indicated a greater extent of peroxide and TBA reactive substances formation in fillets than in whole fish. This is likely due to a greater access of oxygen to fish tissue $[42,46]$ and 
more contact between white muscle tissue and blood contaminants as a result of filleting [7].

Treatment of whole fish with either water, CA or AA did not retard oxidation compared to that of the Blank Control. However, employment of the CA-AA treatment (0.50\%) did offer some protection (months 6 and 9; Table 6) as evident by lower peroxide values. In the case of treated whole fish, direct contact of antioxidant molecules with white muscle tissue and prooxidant molecules present within is more difficult than in the case of a filleted fish product. Present literature accounts for a wide variety of studies concerning minced and filleted fish [12,14-17], but, efforts have been scarce related to whole fish treatment, and those that have, have mostly focused on maintaining the colour stability of rockfish species, such as Sebastolobus alascanus [47], Sebastes ruberriumus and Sebastes alatus [48].

\section{OVERALL CONCLUSION}

According to the present results, the use of CA and AA has turned the fish muscle to be less prone to oxidation than their untreated counterparts. Both acids offer many advantages for being employed as antioxidant molecules during fish processing such as easy availability, high water solubility, low commercial value and a high level allocated for their use, according to European and American administrations [15,49,50]. As a result of a greater accessibility to fish muscle, inhibition of lipid oxidation showed to be easier to be carried out in the case of fillets than whole fish. Accordingly, further studies on the positive role of a CA-AA mixture on oxidation inhibition will be carried 
out to enlarge the shelf life time of whole horse mackerel and fattier fish species during frozen storage, leading to a benefit to both processor and consumer.

\section{ACKNOWLEDGEMENTS}

The authors acknowledge Mr. Marcos Trigo and Mrs. Janet Ares for technical assistance and the Comisión Interministerial de Ciencia y Tecnología (CICyT) for financial support through the research project ALI 99-0869 (2000-2002). 


\section{REFERENCES}

[1] G. Pigott, B. Tucker: Science opens new horizons for marine lipids in human nutrition. Food Rev. Intern. 3 (1987) 105-138.

[2] M. Erickson: Lipid oxidation: Flavor and nutritional quality deterioration in frozen foods. In: Quality in frozen food. Eds. M. Erickson, Y.-C. Hung, Chapman and Hall, New York (USA), 1997, pp. 141-173.

[3] R. Hsieh, J. Kinsella: Oxidation of polyunsaturated fatty acids: mechanisms, products and inhibition with emphasis on fish. Adv. Food Res. Nutr. Res. 33 (1989) 233-341.

[4] P. Harris, J. Tall: Rancidity in fish. In: Rancidity in foods. Eds. J. C. Allen, R. J. Hamilton, Chapman and Hall, London (UK), 1994, pp. 256-272.

[5] R. Ackman: Fatty acids. In: Marine biogenic lipids, fats and oils. Ed. R. Ackman, CRC Press, Boca Raton, FL (USA), Vol. 1, 1989, pp. 103-137.

[6] S. Mohri, S.-Y. Cho, Y. Endo, K. Fujimoto: Linoleate 13(S)-lipoxygenase in sardine skin. J. Agric. Food Chem. 40 (1992) 573-576.

[7] M. Richards, S. Kelleher, H. Hultin: Effect of washing with or without antioxidants on quality retention of mackerel fillets during refrigerated and frozen storage. J. Agric. Food Chem. 46 (1998) 4363-4371.

[8] A. Kamal-Eldin, L. Appelqvist: The chemistry and antioxidant properties of tocopherols and tocotrienols. Lipids 31 (1996) 671-701.

[9] E. Decker: Strategies for manipulating the prooxidative/antioxidative balance of foods to maximize oxidative stability. Trends Food Sci. Technol. 9 (1998) 241248. 
[10] E. Frankel: Natural and biological antioxidants in foods and biological systems. Their mechanism of action, applications and implications. Lipid Technol. July (1995) 77-80.

[11] R. Hamilton, C. Kalu, G. McNeill, F. Padley, J. Pierce: Effects of tocopherols, ascorbyl palmitate, and lecithin on autoxidation of fish oil. J. Am. Oil Chem. Soc. 75 (1998) 813-822.

[12] S. Kelleher, L. Silva, H. Hultin, K. Wilhelm: Inhibition of lipid oxidation during processing of washed, minced Atlantic mackerel. J. Food Sci. 57 (1992) 11031108, 1119.

[13] I. Medina, R. Sacchi, L. Biondi, S. Aubourg, L. Paolillo: Effect of packing media on the oxidation of canned tuna lipids. Antioxidant effectiveness of extra virgin olive oil. J. Agric. Food Chem. 46 (1998) 1150-1157.

[14] K. Vareltzis, D. Koufidis, E. Graviilidou, E. Papavergou, S. Vasiliadou: Effectiveness of a natural rosemary (Rosmarinus officinalis) extract on the stability of filleted and minced fish during frozen storage. Z. Lebensm. Unters. Forsch. 205 (1997) 93-96.

[15] A. Khalil, E. Mansour: Control of lipid oxidation in cooked and uncooked refrigerated carp fillets by antioxidant and packaging combinations. J. Agric. Food Chem. 46 (1998) 1158-1162.

[16] S. Metin, N. Erkan, C. Varlik, N. Aran: Extension of shelf life of chub mackerel (Scomber japonicus Houttuyn 1780) treated with lactic acid. Eur. Food Res. Technol. 213 (2001) 174-177.

[17] S. Aubourg, A. Lugasi, J. Hóvári, C. Piñeiro, V. Lebovics, I. Jakóczi: Damage inhibition during frozen storage of horse mackerel (Trachurus trachurus) fillets by a previous plant extract treatment. J. Food Sci. (2004). In press. 
[18] S. Ponce de León, N. Inoue, H. Shinano: Effect of acetic and citric acids on the growth and activity (VB-N) of Pseumonas sp. and Moraxella sp. Bull. Fac. Fish. Hokkaido Univ. 44 (1993) 80-85.

[19] S. Chawla, V. Venugopal, P. Nair: Gelation of proteins from washed muscle of threadfin bream (Nemipterus japonicus) under mild acidic conditions. J. Food Sci. 61 (1996) 362-371.

[20] M. Gómez-Guillén, P. Montero: Extraction of gelatin from megrim (Lepidorhombus boscii) skins with several organic acids. J. Food Sci. 66 (2001) 213-216.

[21] I. Jaswir, Y. Che Man, D. Kitts: Synergistic effects of rosemary, sage, and citric acid on fatty acid retention of palm olein during deep-fat frying. J. Am. Oil Chem. Soc. 77 (2000) 527-533.

[22] L. Stodolnik, E. Blasiak, H. Broszedzka: Effect of Tween 80, citric acid and acetylsalicylic acids on changes in muscle tissue lipids of Baltic herrings during storage. Chlodnictwo 27 (1992) 29-35.

[23] K. Hwang, J. Regenstein: Protection of menhaden mince lipids from rancidity during frozen storage. J. Food Sci. 54 (1988) 1120-1124.

[24] K. Chapman, I. Sagi, K. Hwang, J. Regenstein: Extra-cold storage of hake and mackerel fillets and mince. J. Food Sci. 58 (1993) 1208-1211.

[25] FAO. Fishery statistics. Food and Agriculture Organization of the United Nations, Rome (Italy), 2002, Yearbook 2000, Vol. 90/1, p. 247.

[26] S. Simeonidou, A. Govaris, K. Vareltzis: Effect of frozen storage on the quality of whole fish and fillets of horse mackerel (Trachurus trachurus) and mediterranean hake (Merluccius mediterranean). Z. Lebensm. Unters. Forsch. 204 (1997) 405-410. 
[27] S. Aubourg: Damage detection in horse mackerel (Trachurus trachurus) during chilled storage. J. Am. Oil Chem. Soc. 78 (2001) 857-862.

[28] E. Bligh, W. Dyer: A rapid method of total extraction and purification. Can. J. Biochem. Physiol. 37 (1959) 911-917.

[29] R. Lowry, I. Tinsley: Rapid colorimetric determination of free fatty acids. J. Am. Oil Chem. Soc. 53 (1976) 470-472.

[30] R. Chapman, J. McKay, The estimation of peroxides in fats and oils by the ferric thiocyanate method. J. Am. Oil Chem. Soc. 26 (1949) 360-363.

[31] W. Vyncke: Direct determination of the thiobarbituric acid value in trichloroacetic acid extracts of fish as a measure of oxidative rancidity. Fette Seifen Anstrichm. 72 (1970) 1084-1087.

[32] S. Aubourg: Review: Recent advances in assessment of marine lipid oxidation by using fluorescence. J. Am. Oil Chem. Soc. 76 (1999) 409-419.

[33] Statsoft: Statistica for Macintosh. Tulsa, Oklahoma (USA): Statsoft and its licensors (1994).

[34] S. Aubourg, C. Sotelo, R. Pérez-Martín: Assessment of quality changes in frozen sardine (Sardina pilchardus) by fluorescence detection. J. Am. Oil Chem. Soc. 75 (1998) 575-580.

[35] S. Aubourg, I. Medina: Influence of storage time on lipid deterioration during cod (Gadus morhua) and haddock (Melanogrammus aeglefinus) frozen storage. J. Sci. Food Agric. 79 (1999) 1943-1948.

[36] G. Piclet : Le poisson aliment. Composition et intérêt nutritionnel. Cah. Nutr. Diét. XXII (1987) 317-335. 
[37] H. Yoshida, I. Kondo, G. Kajimoto: Participation of free fatty acids in the oxidation of purified soybean oil during microwave heating. J. Am. Oil Chem. Soc. 69 (1992) 1136-1140.

[38] K. Miyashita, T. Takagi: Study on the oxidative rate and prooxidant activity of free fatty acids. J. Am. Oil Chem. Soc. 63 (1986) 1380-1384.

[39] S. Aubourg, M. Ugliano: Effect of brine pre-treatment on lipid stability of frozen horse mackerel (Trachurus trachurus). Eur. Food Res. Technol. 215 (2002) 9195.

[40] I. Bratkowska, W. Zwierzykowski: Comparison of complex forming power of rapseed phospholipids and of citric acid during oil autoxidation. Acta Alimentaria Polonica XII (1986) 187-196.

[41] J. Terao: Reactions of lipid hydroperoxides. In: Membrane lipid oxidation. Ed. C. Vigo-Pelfrey, CRC Press, Boca Raton, Fla (USA), 1990, pp. 219-238.

[42] I. Undeland, B. Ekstrand, H. Lingnert: Lipid oxidation in minced herring (Clupea harengus) during frozen storage. Effect of washing and precooking. J. Agric. Food Chem. 46 (1998) 2319-2328.

[43] M. Richards, H. Hultin: Contributions of blood and blood components to lipid oxidation in fish muscle. J. Agric. Food Chem. 50 (2002) 555-564.

[44] E. Decker, H. Hultin: Factors influencing catalysis of lipid oxidation by the soluble fraction of mackerel muscle. J. Food Sci. 55 (1990) 947-950, 953.

[45] K. Hwang, J. Regenstein: Hydrolysis and oxidation of mackerel (Scomber scombrus) mince lipids with $\mathrm{NaOCl}$ and $\mathrm{NaF}$ treatments. J. Aquat. Food Prod. Technol. 4 (1995) 19-30.

[46] J. Kanner, I. Shegalovich, S. Harel, B. Hazan: Muscle lipid peroxidation dependent on oxygen and free metal ions. J. Agric. Food Chem. 36 (1988) 409-412. 
[47] D. Wasson, K. Reppond, T. Kandianis: Antioxidants to preserve rockfish color. J. Food Sci. 56 (1991) 1564-1566.

[48] S. Li, T. Seymour, A. King, M. Morrisey: Color stability and lipid oxidation of rockfish as affected by antioxidant from shrimp shell waste. J. Food Sci. 63 (1998) 438-441.

[49] A. Madrid, J. Madrid, R. Madrid: Tecnología del pescado y productos derivados.

A. Madrid Vicente, Ediciones y Mundi-Prensa Libros, S. A., Madrid (Spain), 1994, pp. 273-276.

[50] J. Giese: Antioxidants: Tools for preventing lipid oxidation. Food Technol. 50 (1996) 73-80. 


\section{TABLE 1}

Free fatty acid (FFA; g FFA/100 g lipids) determination* during frozen storage of horse mackerel fillets that were pretreated under different conditions**

\begin{tabular}{|c|c|c|c|c|}
\hline \multirow[t]{2}{*}{ Treatment } & \multirow[t]{2}{*}{ Raw Value } & \multicolumn{3}{|c|}{ Frozen Storage Time (months) } \\
\hline & & 1 & 3 & 6 \\
\hline Blank Control & $\begin{array}{l}{ }^{\mathrm{w}} 0.30 \\
(0.05)\end{array}$ & $\begin{array}{c}{ }^{\mathrm{x}} 2.0 \mathrm{a} \\
(0.4)\end{array}$ & $\begin{array}{c}\mathrm{y} 4.4 \mathrm{a} \\
(0.3)\end{array}$ & $\begin{array}{c}{ }^{\mathrm{z}} 7.0 \mathrm{ab} \\
(1.2)\end{array}$ \\
\hline Water Control & $\begin{array}{l}{ }^{\mathrm{w}} 0.30 \\
(0.05)\end{array}$ & $\begin{array}{c}{ }^{\mathrm{w}} 1.8 \mathrm{a} \\
(0.4)\end{array}$ & $\begin{array}{c}{ }^{\mathrm{x}} 5.9 \mathrm{a} \\
(1.6)\end{array}$ & $\begin{array}{c}\mathrm{y} 8.0 \mathrm{~b} \\
(0.2)\end{array}$ \\
\hline $0.05 \%$ CA & $\begin{array}{l}{ }^{\mathrm{w}} 0.30 \\
(0.05)\end{array}$ & $\begin{array}{c}\mathrm{x} 1.9 \mathrm{a} \\
(0.7)\end{array}$ & $\begin{array}{c}{ }^{\mathrm{y}} 4.3 \mathrm{a} \\
(0.6)\end{array}$ & $\begin{array}{c}{ }^{\mathrm{y}} 5.0 \mathrm{a} \\
(0.5)\end{array}$ \\
\hline $0.15 \%$ CA & $\begin{array}{l}{ }^{\mathrm{w}} 0.30 \\
(0.05)\end{array}$ & $\begin{array}{c}{ }^{\mathrm{x}} 2.2 \mathrm{a} \\
(0.7)\end{array}$ & $\begin{array}{c}{ }^{\mathrm{y}} 4.0 \mathrm{a} \\
(0.9)\end{array}$ & $\begin{array}{c}{ }^{\mathrm{z}} 7.8 \mathrm{~b} \\
(0.7)\end{array}$ \\
\hline $0.50 \%$ CA & $\begin{array}{l}{ }^{\mathrm{w}} 0.30 \\
(0.05)\end{array}$ & $\begin{array}{c}{ }^{\mathrm{w}} 1.8 \mathrm{a} \\
(0.8)\end{array}$ & $\begin{array}{c}\mathrm{x} 4.5 \mathrm{a} \\
(1.3)\end{array}$ & $\begin{array}{c}\mathrm{y} 7.6 \mathrm{~b} \\
(0.1)\end{array}$ \\
\hline
\end{tabular}

* Mean values of three independent determinations. For each row, means preceded by different superscripts $(\mathrm{w}-\mathrm{z})$ are significantly $(\mathrm{p}<0.05)$ different. For each frozen storage time, means followed by different letters $(a-b)$ are significantly $(p<0.05)$ different. Standard deviations are indicated in parentheses.

** Treatments: Untreated fillets (Blank Control), water treated fillets (Water Control) and citric acid (CA) treated fillets (0.05 \% CA, $0.15 \%$ CA and $0.50 \%$ CA). 


\section{TABLE 2}

Peroxide value (PV; meq active oxygen/kg lipid) determination* during frozen storage of horse mackerel fillets that were pretreated under different conditions ${ }^{* *}$

\begin{tabular}{|c|c|c|c|c|}
\hline \multirow[t]{2}{*}{ Treatment } & \multirow[t]{2}{*}{ Raw Value } & \multicolumn{3}{|c|}{ Frozen Storage Time (months) } \\
\hline & & 1 & 3 & 6 \\
\hline Blank Control & $\begin{array}{l}{ }^{\mathrm{w}} 1.3 \\
(0.5)\end{array}$ & $\begin{array}{c}{ }^{\mathrm{w}} 2.0 \mathrm{a} \\
(0.4)\end{array}$ & $\begin{array}{l}x \\
15.9 c \\
(3.5)\end{array}$ & $\begin{array}{c}\mathrm{y} 49.0 \mathrm{~b} \\
(6.2)\end{array}$ \\
\hline Water Control & $\begin{array}{l}{ }^{\mathrm{w}} 1.3 \\
(0.5)\end{array}$ & $\begin{array}{c}{ }^{\mathrm{w}} 2.0 \mathrm{a} \\
(0.2)\end{array}$ & $\begin{array}{c}{ }^{x} 8.4 \text { b } \\
(1.5)\end{array}$ & $\begin{array}{c}\mathrm{y} 23.8 \mathrm{a} \\
(1.9)\end{array}$ \\
\hline $0.05 \%$ CA & $\begin{array}{l}{ }^{\mathrm{w}} 1.3 \\
(0.5)\end{array}$ & $\begin{array}{c}{ }^{\mathrm{w}} 2.0 \mathrm{a} \\
(0.8)\end{array}$ & $\begin{array}{c}{ }^{\mathrm{w}} 3.8 \mathrm{a} \\
(1.5)\end{array}$ & $\begin{array}{c}\mathrm{x} 26.7 \mathrm{a} \\
(8.8)\end{array}$ \\
\hline $0.15 \%$ CA & $\begin{array}{l}{ }^{\mathrm{w}} 1.3 \\
(0.5)\end{array}$ & $\begin{array}{c}{ }^{\mathrm{w}} 2.7 \mathrm{a} \\
(1.4)\end{array}$ & $\begin{array}{c}{ }^{\mathrm{w}} 6.9 \mathrm{ab} \\
(0.3)\end{array}$ & $\begin{array}{c}\mathrm{x} 34.1 \mathrm{a} \\
(5.4)\end{array}$ \\
\hline $0.50 \% \mathrm{CA}$ & $\begin{array}{l}{ }^{\mathrm{w}} 1.3 \\
(0.5)\end{array}$ & $\begin{array}{c}{ }^{\mathrm{w}} 1.3 \mathrm{a} \\
(0.3)\end{array}$ & $\begin{array}{c}{ }^{\mathrm{w}} 4.7 \mathrm{a} \\
(0.8)\end{array}$ & $\begin{array}{c}{ }^{\mathrm{x}} 31.5 \mathrm{a} \\
(4.0)\end{array}$ \\
\hline
\end{tabular}

* Mean values of three independent determinations. For each row, means preceded by different superscripts $(w-y)$ are significantly $(p<0.05)$ different. For each frozen storage time, means followed by different letters $(a-c)$ are significantly $(p<0.05)$ different. Standard deviations are indicated in parentheses.

** Treatments names as expressed in Table 1. 


\section{TABLE 3}

Thiobarbituric acid index (TBA-i; mg malondialdehyde equivalents/kg fish muscle) determination* during frozen storage of horse mackerel fillets that were pretreated under different conditions**

\begin{tabular}{|c|c|c|c|c|}
\hline \multirow[t]{2}{*}{ Treatment } & \multirow[t]{2}{*}{ Raw Value } & \multicolumn{3}{|c|}{ Frozen Storage Time (months) } \\
\hline & & 1 & 3 & 6 \\
\hline Blank Control & $\begin{array}{l}{ }^{\mathrm{w}} 0.07 \\
(0.01)\end{array}$ & $\begin{array}{c}{ }^{\mathrm{x}} 0.62 \text { c } \\
(0.13)\end{array}$ & $\begin{array}{c}{ }^{\mathrm{x}} 0.81 \text { c } \\
(0.08)\end{array}$ & $\begin{array}{c}{ }^{\mathrm{x}} 0.96 \mathrm{~b} \\
(0.16)\end{array}$ \\
\hline Water Control & $\begin{array}{l}{ }^{\mathrm{w}} 0.07 \\
(0.01)\end{array}$ & $\begin{array}{c}{ }^{\mathrm{x}} 0.42 \mathrm{~b} \\
(0.08)\end{array}$ & $\begin{array}{c}\mathrm{y} 0.67 \text { b } \\
(0.05)\end{array}$ & $\begin{array}{c}{ }^{\mathrm{y}} 0.76 \mathrm{ab} \\
(0.22)\end{array}$ \\
\hline $0.05 \% \mathrm{CA}$ & $\begin{array}{l}{ }^{\mathrm{w}} 0.07 \\
(0.01)\end{array}$ & $\begin{array}{c}{ }^{\mathrm{x}} 0.39 \mathrm{~b} \\
(0.09)\end{array}$ & $\begin{array}{c}{ }^{\mathrm{x}} 0.36 \mathrm{a} \\
(0.05)\end{array}$ & $\begin{array}{c}{ }^{\mathrm{x}} 0.45 \text { a } \\
(0.14)\end{array}$ \\
\hline $0.15 \% \mathrm{CA}$ & $\begin{array}{l}{ }^{\mathrm{w}} 0.07 \\
(0.01)\end{array}$ & $\begin{array}{c}\text { wx } 0.37 \text { b } \\
(0.04)\end{array}$ & $\begin{array}{c}\text { wx } 0.37 \text { a } \\
(0.07)\end{array}$ & $\begin{array}{c}{ }^{\mathrm{y}} 0.54 \text { a } \\
(0.26)\end{array}$ \\
\hline $0.50 \%$ CA & $\begin{array}{l}{ }^{\mathrm{w}} 0.07 \\
(0.01)\end{array}$ & $\begin{array}{c}{ }^{\mathrm{x}} 0.17 \mathrm{a} \\
(0.04)\end{array}$ & $\begin{array}{c}{ }^{\mathrm{y}} 0.29 \text { a } \\
(0.04)\end{array}$ & $\begin{array}{c}{ }^{\mathrm{z}} 0.48 \mathrm{a} \\
(0.08)\end{array}$ \\
\hline
\end{tabular}

* Mean values of three independent determinations. For each row, means preceded by different superscripts $(\mathrm{w}-\mathrm{z})$ are significantly $(\mathrm{p}<0.05)$ different. For each frozen storage time, means followed by different letters $(a-c)$ are significantly $(p<0.05)$ different. Standard deviations are indicated in parentheses.

** Treatments names as expressed in Table 1. 


\section{TABLE 4}

Fluorescence ratio (FR) determination* during frozen storage of horse mackerel fillets that were pretreated under different conditions**

\begin{tabular}{|c|c|c|c|c|}
\hline \multirow[t]{2}{*}{ Treatment } & \multirow[t]{2}{*}{ Raw Value } & \multicolumn{3}{|c|}{ Frozen Storage Time (months) } \\
\hline & & 1 & 3 & 6 \\
\hline Blank Control & $\begin{array}{l}{ }^{\mathrm{w}} 0.17 \\
(0.03)\end{array}$ & $\begin{array}{c}{ }^{\mathrm{w}} 0.25 \mathrm{a} \\
(0.04)\end{array}$ & $\begin{array}{c}{ }^{\mathrm{x}} 0.45 \mathrm{a} \\
(0.15)\end{array}$ & $\begin{array}{c}\mathrm{y} 1.59 \text { с } \\
(0.04)\end{array}$ \\
\hline Water Control & $\begin{array}{l}{ }^{\mathrm{w}} 0.17 \\
(0.03)\end{array}$ & $\begin{array}{c}{ }^{\mathrm{w}} 0.24 \mathrm{a} \\
(0.06)\end{array}$ & $\begin{array}{c}{ }^{\mathrm{w}} 0.37 \mathrm{a} \\
(0.08)\end{array}$ & $\begin{array}{l}\text { x } 1.36 \text { bc } \\
(0.33)\end{array}$ \\
\hline $0.05 \%$ CA & $\begin{array}{l}{ }^{\mathrm{w}} 0.17 \\
(0.03)\end{array}$ & $\begin{array}{c}{ }^{\mathrm{w}} 0.24 \mathrm{a} \\
(0.03)\end{array}$ & $\begin{array}{c}{ }^{\mathrm{w}} 0.32 \text { a } \\
(0.05)\end{array}$ & $\begin{array}{c}{ }^{\mathrm{x}} 0.96 \mathrm{ab} \\
(0.19)\end{array}$ \\
\hline $0.15 \%$ CA & $\begin{array}{l}{ }^{\mathrm{w}} 0.17 \\
(0.03)\end{array}$ & $\begin{array}{c}{ }^{\mathrm{w}} 0.25 \mathrm{a} \\
(0.08)\end{array}$ & $\begin{array}{c}{ }^{\mathrm{w}} 0.31 \mathrm{a} \\
(0.05)\end{array}$ & $\begin{array}{c}{ }^{\mathrm{x}} 0.75 \mathrm{a} \\
(0.16)\end{array}$ \\
\hline $0.50 \% \mathrm{CA}$ & $\begin{array}{l}{ }^{\mathrm{w}} 0.17 \\
(0.03)\end{array}$ & $\begin{array}{c}{ }^{\mathrm{w}} 0.20 \mathrm{a} \\
(0.04)\end{array}$ & $\begin{array}{c}{ }^{\mathrm{w}} 0.26 \text { a } \\
(0.08)\end{array}$ & $\begin{array}{c}{ }^{\mathrm{x}} 0.60 \mathrm{a} \\
(0.20)\end{array}$ \\
\hline
\end{tabular}

* Mean values of three independent determinations. For each row, means preceded by different superscripts $(w-y)$ are significantly $(p<0.05)$ different. For each frozen storage time, means followed by different letters $(a-c)$ are significantly $(\mathrm{p}<0.05)$ different. Standard deviations are indicated in parentheses.

** Treatments names as expressed in Table 1. 


\section{TABLE 5}

Free fatty acid (FFA; g FFA/100 g lipids) determination* during frozen storage of whole horse mackerel that was pretreated under different conditions**

\begin{tabular}{|c|c|c|c|c|c|}
\hline \multirow{2}{*}{ Treatment } & \multirow{2}{*}{ Raw Value } & \multicolumn{4}{|c|}{ Frozen Storage Time (months) } \\
\hline & & 1 & 3 & 6 & 9 \\
\hline $\begin{array}{c}\text { Blank } \\
\text { Control } \\
\end{array}$ & $\begin{array}{l}{ }^{\mathrm{w}} 0.28 \\
(0.04)\end{array}$ & $\begin{array}{c}\mathrm{wx} 1.1 \mathrm{a} \\
(0.5)\end{array}$ & $\begin{array}{c}{ }^{x y} 3.9 \text { a } \\
(2.4)\end{array}$ & $\begin{array}{c}\mathrm{yz} 5.6 \mathrm{a} \\
(2.9)\end{array}$ & $\begin{array}{l}{ }^{\mathrm{z}} 8.0 \mathrm{ab} \\
(1.4)\end{array}$ \\
\hline $\begin{array}{c}\text { Water } \\
\text { Control }\end{array}$ & $\begin{array}{l}{ }^{\mathrm{w}} 0.28 \\
(0.04)\end{array}$ & $\begin{array}{c}{ }^{\mathrm{w}} 1.3 \mathrm{a} \\
(0.4)\end{array}$ & $\begin{array}{c}{ }^{\mathrm{x}} 3.8 \mathrm{a} \\
(0.8)\end{array}$ & $\begin{array}{c}\mathrm{y} 10.2 \mathrm{~b} \\
(0.9)\end{array}$ & $\begin{array}{l}\mathrm{z} 11.8 \mathrm{~b} \\
(1.1)\end{array}$ \\
\hline $0.50 \% \mathrm{AA}$ & $\begin{array}{l}{ }^{\mathrm{w}} 0.28 \\
(0.04)\end{array}$ & $\begin{array}{c}{ }^{\mathrm{w}} 1.6 \mathrm{ab} \\
(0.6)\end{array}$ & $\begin{array}{l}{ }^{x} 3.9 \text { a } \\
(1.356)\end{array}$ & $\begin{array}{c}{ }^{\mathrm{y}} 8.2 \mathrm{ab} \\
(1.9)\end{array}$ & $\begin{array}{c}{ }^{\mathrm{y}} 9.7 \mathrm{ab} \\
(2.0)\end{array}$ \\
\hline $0.50 \%$ CA & $\begin{array}{l}{ }^{\mathrm{w}} 0.28 \\
(0.04)\end{array}$ & $\begin{array}{l}{ }^{\mathrm{w}} 1.9 \mathrm{ab} \\
(0.5)\end{array}$ & $\begin{array}{c}{ }^{\mathrm{w}} 3.2 \mathrm{a} \\
(1.4)\end{array}$ & $\begin{array}{l}{ }^{\mathrm{x}} 6.9 \mathrm{ab} \\
(2.3)\end{array}$ & $\begin{array}{l}{ }^{\mathrm{x}} 8.6 \mathrm{ab} \\
(2.7)\end{array}$ \\
\hline $\begin{array}{c}0.50 \% \\
\text { AA-CA }\end{array}$ & $\begin{array}{l}{ }^{\mathrm{w}} 0.28 \\
(0.04)\end{array}$ & $\begin{array}{c}{ }^{\mathrm{w}} 2.9 \mathrm{~b} \\
(1.6)\end{array}$ & $\begin{array}{c}{ }^{\mathrm{w}} 2.8 \mathrm{a} \\
(0.5)\end{array}$ & $\begin{array}{c}{ }^{\mathrm{x}} 6.9 \mathrm{ab} \\
(2.1)\end{array}$ & $\begin{array}{c}\mathrm{x} 7.7 \mathrm{a} \\
(3.0)\end{array}$ \\
\hline $\begin{array}{r}0.25 \% \\
\text { AA-CA } \\
\end{array}$ & $\begin{array}{l}{ }^{\mathrm{w}} 0.28 \\
(0.04)\end{array}$ & $\begin{array}{c}{ }^{x} 3.0 \quad b \\
(0.8)\end{array}$ & $\begin{array}{c}\mathrm{x} 3.0 \mathrm{a} \\
(0.7) \\
\end{array}$ & $\begin{array}{c}{ }^{\mathrm{y}} 5.9 \text { a } \\
(0.8) \\
\end{array}$ & $\begin{array}{l}{ }^{\mathrm{z}} 9.6 \mathrm{ab} \\
(2.8)\end{array}$ \\
\hline
\end{tabular}

* Mean values of three independent determinations. For each row, means preceded by different superscripts $(w-z)$ are significantly $(\mathrm{p}<0.05)$ different. For each frozen storage time, means followed by different letters (a-b) are significantly $(\mathrm{p}<0.05)$ different. Standard deviations are indicated in parentheses.

** Treatments: Untreated fish (Blank Control), water treated fish (Water Control), $0.50 \%$ ascorbic acid (AA) treated fish (0.50 \% AA), 0.50\% citric acid (CA) treated fish (0.50\% CA), 0.50\% AA + 0.50\% CA treated fish (0.50\% AACA), $0.25 \% \mathrm{AA}+0.25 \%$ CA treated fish (0.25\% AA-CA). 


\section{TABLE 6}

Peroxide value (PV; meq active oxygen/kg lipid) determination* during frozen storage of whole horse mackerel that was pretreated under different conditions**

\begin{tabular}{|c|c|c|c|c|c|}
\hline \multirow[t]{2}{*}{ Treatment } & \multirow[t]{2}{*}{ Raw Value } & \multicolumn{4}{|c|}{ Frozen Storage Time (months) } \\
\hline & & 1 & 3 & 6 & 9 \\
\hline $\begin{array}{c}\text { Blank } \\
\text { Control }\end{array}$ & $\begin{array}{c}{ }^{\mathrm{w}} 2.21 \\
(0.589)\end{array}$ & $\begin{array}{c}{ }^{\mathrm{wx}} 3.8 \mathrm{a} \\
(1.6)\end{array}$ & $\begin{array}{c}{ }^{\mathrm{w}} 3.7 \mathrm{a} \\
(0.9)\end{array}$ & $\begin{array}{c}{ }^{\mathrm{x}} 6.9 \mathrm{~b} \\
(2.1)\end{array}$ & $\begin{array}{c}{ }^{\mathrm{y}} 12.9 \mathrm{~b} \\
(1.7)\end{array}$ \\
\hline $\begin{array}{c}\text { Water } \\
\text { Control }\end{array}$ & $\begin{array}{l}{ }^{\mathrm{w}} 2.21 \\
(0.589)\end{array}$ & $\begin{array}{c}{ }^{x y} 4.2 \text { a } \\
(0.4)\end{array}$ & $\begin{array}{c}\mathrm{c}^{\mathrm{wx}} 3.4 \mathrm{a} \\
(1.9)\end{array}$ & $\begin{array}{c}{ }^{\mathrm{y}} 6.6 \mathrm{~b} \\
(2.2)\end{array}$ & $\begin{array}{l}{ }^{\mathrm{z}} 12.2 \mathrm{~b} \\
(0.3)\end{array}$ \\
\hline $0.50 \% \mathrm{AA}$ & $\begin{array}{l}{ }^{\mathrm{w}} 2.21 \\
(0.589)\end{array}$ & $\begin{array}{c}{ }^{\mathrm{w}} 4.1 \mathrm{a} \\
(1.6)\end{array}$ & $\begin{array}{c}{ }^{\mathrm{w}} 3.9 \mathrm{ab} \\
(1.3)\end{array}$ & $\begin{array}{c}{ }^{\mathrm{w}} 4.8 \mathrm{ab} \\
(0.8)\end{array}$ & $\begin{array}{l}{ }^{\mathrm{x}} 12.0 \mathrm{~b} \\
(3.1)\end{array}$ \\
\hline $0.50 \% \mathrm{CA}$ & $\begin{array}{l}{ }^{\mathrm{w}} 2.21 \\
(0.589)\end{array}$ & $\begin{array}{c}\mathrm{c}^{\mathrm{wx}} 2.5 \mathrm{a} \\
(1.6)\end{array}$ & $\begin{array}{c}{ }^{\mathrm{x}} 5.8 \mathrm{~b} \\
(0.8)\end{array}$ & $\begin{array}{c}{ }^{\mathrm{x}} 5.6 \mathrm{ab} \\
(1.6)\end{array}$ & $\begin{array}{c}{ }^{\mathrm{y}} 12.6 \mathrm{~b} \\
(4.0)\end{array}$ \\
\hline $\begin{array}{r}0.50 \% \\
\text { AA-CA }\end{array}$ & $\begin{array}{l}{ }^{w} 2.21 \\
(0.589)\end{array}$ & $\begin{array}{c}{ }^{\mathrm{x}} 3.8 \mathrm{a} \\
(0.3)\end{array}$ & $\begin{array}{c}{ }^{\mathrm{x}} 3.7 \mathrm{a} \\
(0.9)\end{array}$ & $\begin{array}{c}{ }^{\mathrm{x}} 2.9 \mathrm{a} \\
(0.5)\end{array}$ & $\begin{array}{c}{ }^{\mathrm{y}} 6.5 \mathrm{a} \\
(1.4)\end{array}$ \\
\hline $\begin{array}{r}0.25 \% \\
\text { AA-CA } \\
\end{array}$ & $\begin{array}{l}{ }^{\mathrm{w}} 2.21 \\
(0.589)\end{array}$ & $\begin{array}{c}\mathrm{wx} 2.9 \mathrm{a} \\
(1.4)\end{array}$ & $\begin{array}{c}\mathrm{wx} 2.8 \mathrm{a} \\
(0.2)\end{array}$ & $\begin{array}{c}x .3 \text { a } \\
(0.9)\end{array}$ & $\begin{array}{c}{ }^{\mathrm{y}} 9.5 \mathrm{ab} \\
(1.9)\end{array}$ \\
\hline
\end{tabular}

* Mean values of three independent determinations. For each row, means preceded by different superscripts $(w-z)$ are significantly $(\mathrm{p}<0.05)$ different. For each frozen storage time, means followed by different letters $(a-b)$ are significantly $(p<0.05)$ different. Standard deviations are indicated in parentheses.

** Treatments names as expressed in Table 5. 


\section{TABLE 7}

Thiobarbituric acid index (TBA-i; mg malondialdehyde equivalents/kg fish muscle) determination* during frozen storage of whole horse mackerel that was pretreated under different conditions**

\begin{tabular}{|c|c|c|c|c|c|}
\hline \multirow[t]{2}{*}{ Treatment } & \multirow[t]{2}{*}{ Raw Value } & \multicolumn{4}{|c|}{ Frozen Storage Time (months) } \\
\hline & & 1 & 3 & 6 & 9 \\
\hline $\begin{array}{c}\text { Blank } \\
\text { Control }\end{array}$ & $\begin{array}{l}{ }^{\mathrm{w}} 0.09 \\
(0.02)\end{array}$ & $\begin{array}{c}{ }^{\mathrm{x}} 0.23 \text { a } \\
(0.12)\end{array}$ & $\begin{array}{c}{ }^{x y} 0.37 \text { a } \\
(0.16)\end{array}$ & $\begin{array}{c}{ }^{\mathrm{y}} 0.47 \mathrm{~b} \\
(0.06)\end{array}$ & $\begin{array}{c}{ }^{\mathrm{y}} 0.49 \mathrm{a} \\
(0.12)\end{array}$ \\
\hline $\begin{array}{c}\text { Water } \\
\text { Control }\end{array}$ & $\begin{array}{l}{ }^{\mathrm{w}} 0.09 \\
(0.02)\end{array}$ & $\begin{array}{c}{ }^{\mathrm{x}} 0.24 \mathrm{a} \\
(0.03)\end{array}$ & $\begin{array}{c}{ }^{\mathrm{xy}} 0.32 \mathrm{a} \\
(0.09)\end{array}$ & $\begin{array}{c}{ }^{\mathrm{y}} 0.38 \mathrm{ab} \\
(0.09)\end{array}$ & $\begin{array}{c}{ }^{\mathrm{y}} 0.40 \mathrm{a} \\
(0.09)\end{array}$ \\
\hline $0.50 \%$ AA & $\begin{array}{l}{ }^{\mathrm{w}} 0.09 \\
(0.02)\end{array}$ & $\begin{array}{c}{ }^{\mathrm{x}} 0.29 \mathrm{a} \\
(0.07)\end{array}$ & $\begin{array}{c}{ }^{\mathrm{xy}} 0.34 \mathrm{a} \\
(0.09)\end{array}$ & $\begin{array}{c}{ }^{\mathrm{y}} 0.32 \mathrm{a} \\
(0.03)\end{array}$ & $\begin{array}{c}{ }^{\mathrm{z}} 0.49 \mathrm{a} \\
(0.13)\end{array}$ \\
\hline $0.50 \% \mathrm{CA}$ & $\begin{array}{l}{ }^{\mathrm{w}} 0.09 \\
(0.02)\end{array}$ & $\begin{array}{c}{ }^{\mathrm{x}} 0.30 \mathrm{a} \\
(0.04)\end{array}$ & $\begin{array}{c}{ }^{\mathrm{x}} 0.26 \mathrm{a} \\
(0.03)\end{array}$ & $\begin{array}{c}{ }^{\mathrm{x}} 0.33 \mathrm{a} \\
(0.03)\end{array}$ & $\begin{array}{c}{ }^{\mathrm{y}} 0.45 \mathrm{a} \\
(0.07)\end{array}$ \\
\hline $\begin{array}{r}0.50 \% \\
\text { AA-CA }\end{array}$ & $\begin{array}{l}{ }^{\mathrm{w}} 0.09 \\
(0.02)\end{array}$ & $\begin{array}{l}{ }^{\mathrm{x}} 0.24 \mathrm{a} \\
(0.08)\end{array}$ & $\begin{array}{c}{ }^{\mathrm{x}} 0.22 \mathrm{a} \\
(0.03)\end{array}$ & $\begin{array}{c}{ }^{\mathrm{x}} 0.33 \mathrm{a} \\
(0.13)\end{array}$ & $\begin{array}{c}{ }^{\mathrm{x}} 0.37 \mathrm{a} \\
(0.08)\end{array}$ \\
\hline $\begin{array}{c}0.25 \% \\
\text { AA-CA }\end{array}$ & $\begin{array}{l}{ }^{\mathrm{w}} 0.09 \\
(0.02)\end{array}$ & $\begin{array}{c}{ }^{\mathrm{x}} 0.24 \mathrm{a} \\
(0.10)\end{array}$ & $\begin{array}{c}{ }^{\mathrm{y}} 0.41 \mathrm{a} \\
(0.12)\end{array}$ & $\begin{array}{c}{ }^{\mathrm{xy}} 0.37 \mathrm{ab} \\
(0.03)\end{array}$ & $\begin{array}{c}{ }^{\mathrm{y}} 0.41 \mathrm{a} \\
(0.01)\end{array}$ \\
\hline
\end{tabular}

* Mean values of three independent determinations. For each row, means preceded by different superscripts $(\mathrm{w}-\mathrm{z})$ are significantly $(\mathrm{p}<0.05)$ different. For each frozen storage time, means followed by different letters $(a-b)$ are significantly $(\mathrm{p}<0.05)$ different. Standard deviations are indicated in parentheses.

** Treatments names as expressed in Table 5. 


\section{TABLE 8}

Fluorescence ratio (FR) determination* during frozen storage of whole horse mackerel that was pretreated under different conditions**

\begin{tabular}{|c|c|c|c|c|c|}
\hline \multirow{2}{*}{ Treatment } & \multirow{2}{*}{ Raw Value } & \multicolumn{4}{|c|}{ Frozen Storage Time (months) } \\
\hline & & 1 & 3 & 6 & 9 \\
\hline $\begin{array}{c}\text { Blank } \\
\text { Control } \\
\end{array}$ & $\begin{array}{l}{ }^{\mathrm{w}} 0.11 \\
(0.03) \\
\end{array}$ & $\begin{array}{c}{ }^{\mathrm{wx}} 0.47 \text { b } \\
(0.22)\end{array}$ & $\begin{array}{c}{ }^{\mathrm{w}} 0.34 \mathrm{a} \\
(0.10)\end{array}$ & $\begin{array}{c}{ }^{\mathrm{x}} 0.85 \mathrm{a} \\
(0.37)\end{array}$ & $\begin{array}{c}{ }^{\mathrm{y}} 1.66 \mathrm{a} \\
(0.19) \\
\end{array}$ \\
\hline $\begin{array}{c}\text { Water } \\
\text { Control }\end{array}$ & $\begin{array}{l}{ }^{\mathrm{w}} 0.11 \\
(0.03)\end{array}$ & $\begin{array}{c}{ }^{\mathrm{wx}} 0.31 \mathrm{ab} \\
(0.03)\end{array}$ & $\begin{array}{c}\mathrm{wx} 0.36 \mathrm{a} \\
(0.29)\end{array}$ & $\begin{array}{c}{ }^{x} 0.60 \text { a } \\
(0.25)\end{array}$ & $\begin{array}{c}{ }^{\mathrm{y}} 1.70 \mathrm{a} \\
(0.12)\end{array}$ \\
\hline $0.50 \% \mathrm{AA}$ & $\begin{array}{l}{ }^{\mathrm{w}} 0.11 \\
(0.03)\end{array}$ & $\begin{array}{c}{ }^{\mathrm{wX}} 0.41 \mathrm{ab} \\
(0.17)\end{array}$ & $\begin{array}{c}{ }^{\mathrm{wx}} 0.43 \mathrm{a} \\
(0.05)\end{array}$ & $\begin{array}{c}{ }^{\mathrm{x}} 0.62 \mathrm{a} \\
(0.14)\end{array}$ & $\begin{array}{c}{ }^{\mathrm{y}} 1.49 \mathrm{a} \\
(0.32)\end{array}$ \\
\hline $0.50 \% \mathrm{CA}$ & $\begin{array}{l}{ }^{\mathrm{w}} 0.11 \\
(0.03) \\
\end{array}$ & $\begin{array}{c}{ }^{\mathrm{wx}} 0.43 \text { ab } \\
(0.22)\end{array}$ & $\begin{array}{c}{ }^{\mathrm{w}} 0.26 \mathrm{a} \\
(0.06)\end{array}$ & $\begin{array}{c}{ }^{\mathrm{x}} 0.77 \mathrm{a} \\
(0.30)\end{array}$ & $\begin{array}{c}\mathrm{y} 1.76 \mathrm{a} \\
(0.37)\end{array}$ \\
\hline $\begin{array}{c}0.50 \% \\
\text { AA-CA }\end{array}$ & $\begin{array}{l}{ }^{\mathrm{w}} 0.11 \\
(0.03)\end{array}$ & $\begin{array}{c}{ }^{\mathrm{w}} 0.21 \mathrm{a} \\
(0.04)\end{array}$ & $\begin{array}{c}{ }^{\mathrm{w}} 0.38 \mathrm{a} \\
(0.04)\end{array}$ & $\begin{array}{c}{ }^{\mathrm{x}} 0.79 \text { a } \\
(0.17)\end{array}$ & $\begin{array}{c}\mathrm{y} 1.24 \mathrm{a} \\
(0.48)\end{array}$ \\
\hline $\begin{array}{r}0.25 \% \\
\text { AA-CA } \\
\end{array}$ & $\begin{array}{l}{ }^{\mathrm{w}} 0.11 \\
(0.03)\end{array}$ & $\begin{array}{c}{ }^{\mathrm{w}} 0.21 \mathrm{a} \\
(0.07)\end{array}$ & $\begin{array}{c}{ }^{\mathrm{wx}} 0.35 \text { a } \\
(0.19)\end{array}$ & $\begin{array}{c}{ }^{x} 0.63 \text { a } \\
(0.11)\end{array}$ & $\begin{array}{c}{ }^{\mathrm{y}} 1.45 \mathrm{a} \\
(0.32)\end{array}$ \\
\hline
\end{tabular}

* Mean values of three independent determinations. For each row, means preceded by different superscripts $(w-y)$ are significantly $(p<0.05)$ different. For each frozen storage time, means followed by different letters $(a-b)$ are significantly $(p<0.05)$ different. Standard deviations are indicated in parentheses.

** Treatments names as expressed in Table 5. 